\title{
Family presence during cardiopulmonary resuscitation and invasive procedures: a meta-synthesis
}

\author{
Presença da família durante ressuscitação cardiopulmonar \\ e procedimentos invasivos: uma metassíntese \\ Presencia de la familia durante resucitación cardiopulmonar \\ y procedimientos invasivos: una metasíntesis
}

How to cite this article:

Barreto MS, Peruzzo HE, Garcia-Vivar C, Marcon SS. Family presence during cardiopulmonary resuscitation and invasive procedures: a meta-synthesis. Rev Esc Enferm USP. 2019;53:e03435. DOI: http://dx.doi.org/10.1590/S1980-220X2018001303435

\author{
Mayckel da Silva Barreto ${ }^{1}$ \\ Hellen Emília Peruzzo ${ }^{1}$ \\ Cristina Garcia-Vivar ${ }^{2}$ \\ Sonia Silva Marcon ${ }^{1}$ \\ 1 Universidade Estadual de Maringá, \\ Maringá, PR, Brazil. \\ ${ }^{2}$ Universidade de Navarra, \\ Pamplona, Navarra, Spain.
}

\begin{abstract}
Objective: To synthesize the best qualitative evidence regarding the perception of family members, patients and health professionals about family presence during cardiopulmonary resuscitation and invasive procedures. Method: Systematic review with meta-synthesis performed in the databases of Web of Science, Scopus, CINAHL, PsycINFO, LILACS, MEDLINE, Embase and VHL. Articles published between 2010 and 2017 were included and evaluated with use of the Qualitative Data Extraction Instrument. Results: In total, were found 2,391 articles, out of which 26 were selected, and 24 were analyzed. The identified meta-theme was 'A pendular perspective: different views on family presence during cardiopulmonary resuscitation and invasive procedures', which is supported by the following themes: Benefits resulting from family presence; Disadvantages and/or limiting factors of family presence; and Context: environmental, sociocultural and care factors influencing the perception of family presence. Conclusion: The perception of family members, patients and professionals about family presence is still controversial. The sensitization of these subjects can potentiate the practice by making it more systematized and qualified.
\end{abstract}

\section{DESCRIPTORS}

Cardiopulmonary Resuscitation; Emergency Medical Services; Family relations; Professional-Family Relations; Emergency Nursing; Review. 


\section{INTRODUCTION}

Based on the assumptions of the Patient and FamilyCentered Care (PFCC), there is now an expectation that regardless of the care context, patients' family members should also be included and considered in health care $^{(1)}$. Consequently, family presence during cardiopulmonary resuscitation and invasive procedures - also called family presence at the bedside - tends to grow in health services ${ }^{(2)}$. After the first report in the literature in $1987^{(3)}$, the practice began to be explored in several studies, in which results showed that when family members are present, they experience an emotionally protective effect that minimizes the traumatic damages inherent in their feeling of powerlessness ${ }^{(4-6)}$. In addition, family presence satisfies their need to "be with" their loved one during a critical and acute illness ${ }^{(7)}$. Among other aspects, family members want to provide information to the health team, provide safety and emotional and spiritual comfort to the patient, and even say goodbye ${ }^{(2,4)}$.

In spite of the concern about the possible emotional responses and suffering of their relatives, people who experienced family presence at the bedside, which theoretically approaches the PFCC proposal, perceived this experience positively in most cases ${ }^{(7)}$. They understand that family presence provides an environment of confidence and tranquility, which is reflected in a best confrontation of the situation ${ }^{(7-8)}$. Health professionals also identified benefits with family presence, and the main one is the possibility of remembering the patient not only as a disease, but as a person who "belongs to someone"(9). This directly converges in greater humanization of care $^{(9)}$ and increases subjects' satisfaction with the health service ${ }^{(5-6)}$.

Despite several positive aspects shown in studies, family presence is still inconsistent and unsystematic ${ }^{(5)}$ given the divergent opinions of researchers and health professionals. Many professionals perceive families as potential evaluators of care, which would increase the possibilities of legal proceedings ${ }^{(10)}$. Moreover, they fear that family members may interfere with the performance of procedures, or even get traumatized with the care scenes, violate the confidentiality of care, interfere with the teaching of residents, increase the team's feelings of stress during care and of impotence before patients' death ${ }^{(10-15)}$.

The existence of several studies of different methodological approaches demonstrates the need for a compilation of the best and most current scientific evidence about family presence during resuscitation and invasive procedures. Integrative reviews ${ }^{(16)}$ and systematic quantitative reviews of the literature ${ }^{(17-18)}$, including meta-analysis ${ }^{(19)}$ on the theme have already been conducted. On the other hand, only one review was found including qualitative studies developed with health professionals and family members ${ }^{(20)}$. In this study, we analyzed 25 articles published between 1985 and 2009. The results allowed the conclusion that there is a tension between the family's belief that being present is a right, and the professionals' belief that they must have control over circumstances of the practice. Most family members described their presence as an opportunity for personal comfort and closure, but professionals were wary of families being traumatized by the scenes ${ }^{(20)}$.

Therefore, knowledge must be updated and expanded through analysis of the most recent literature and inclusion of studies with participation of patients. The findings listed and synthesized here have the potential to sensitize professionals and managers of emergency units in order to discuss the importance of PFCC by subsidizing the development of permissive institutional policies with family presence during care based on local reality. Given the considerations presented, the objective of this review was to synthesize the best qualitative evidence regarding the perception of family members, patients and health professionals about family presence during cardiopulmonary resuscitation and invasive procedures.

\section{METHOD}

\section{TyPE OF STUDY}

In this systematic review was adopted the Joanna Briggs Institute (JBI) meta-synthesis methodology ${ }^{(21)}$. For its development, the following steps were considered: 1) Approach of the theme and formulation of the research question. The following guiding question was developed: what is the perception of family members, patients and health professionals about family presence during cardiopulmonary resuscitation and invasive procedures in the prehospital and hospital setting?; 2) Definition of information evaluated in the articles; 3) Selection of databases and descriptors; 4) Selection of studies based on previously established criteria; 5) Evaluation of the methodological rigor of empirical studies; 6) Collection and registration of the information of articles considered for review in a specific instrument; and 7) Synthesis of findings with development of qualitative metasynthesis ${ }^{(21)}$. Although the project of this review was not submitted to the JBI, all steps proposed by this entity were followed, and are best described in the following sections.

\section{INCLUSION AND EXCLUSION CRITERIA OF ARTICLES}

The PICO structure was used for defining the inclusion/exclusion criteria as follows: Population - adult patients (aged 18 years or older) in critical/emergency care; family members of patients (affectional bond or consanguinity) and health professionals (doctors, nurses, nursing technicians, physiotherapists and hospital chaplains). Phenomenon of Interest - perception of patients, family members and health professionals about family presence during cardiopulmonary resuscitation and invasive procedures. Context - prehospital and hospital emergency care settings (emergency and intensive care units). Outcome - subjective description of the perception of phenomenon.

Thus, qualitative or mixed method studies conducted with adult patients, family members and health professionals published between January 2010 and December 2017 were selected. This period was defined because there is already a meta-synthesis on the subject with studies published between 1985 and 2009 ${ }^{(20)}$, and because the most current scientific evidence was sought. Electronic texts available in 
English, Portuguese and Spanish were considered, because the authors are fluent in these three languages, and these are some of the most widely used scientific languages in the world. In the case of articles, the inclusion criterion of the publication journal being peer reviewed was also adopted. This preliminary screening sought to select only articles previously evaluated for their quality.

\section{SeARCH STRATEGIES}

Initially, the search was performed in March 2017 and updated in January 2018. The evaluation and analysis of results were performed between March and June 2017 with completion in January 2018.

The following combination of descriptors (MeSH) in English was used to conduct the search in PubMed and in other databases with small adaptations, according to their specificities: "Family Presence" OR "Family Witnessed Resuscitation" OR "Family Presence during Resuscitation" OR "Family Presence During Invasive Procedures"; with date limits [01/01/2010 to 31/12/2017]; species [humans] and language [Portuguese, English or Spanish]. A librarian was consulted to promote rigor in the search process. Ten databases were used, namely: Web of Science; Scopus; Cumulative Index to Nursing \&Allied Health Literature (CINAHL); Latin American and Caribbean Health Sciences Literature (LILACS); PsycINFO of the American Psychological Association; Embase; Virtual Health Library (VHL); Medical Literature Analysis and Retrieval System Online (MEDLINE-PubMed); VHL-psychology Brazil and Sociological abstracts. However, the last two databases did not return files in the search and therefore were not included in Figure 1.

In accordance with the principles suggested by $\mathrm{JBI}^{(21)}$, the same descriptors were inserted into five gray literature databases (Index to Theses, Digital Dissertations, CAPES Theses and Dissertations Bank, Networked Digital Library of Theses and Dissertations and New York Academy of Medicine Grey Literature Report), but no material that answered the review question was identified.

\section{SELECTION OF ARTICLES AND QUALITY EVALUATION}

There were 2,391 articles (247 in the Web of Science, 303 in Scopus, 121 in CINAHL, 1,595 in MEDLINE,
118 in LILACS, two in VHL, two in Embase and three in PsycINFO). After reading titles and abstracts, 2,307 studies were excluded. Of the 84 remaining articles, 57 were rejected because they were duplicates and one was in German. Thus, out of 2,391 articles, 26 met the inclusion criteria and answered the guiding question. However, in the quality evaluation, two articles did not reach $70 \%$ or more of positive responses in the Critical Appraisal Checklist for Interpretive \& Critical Research (QARI) ${ }^{(21)}$. Thus, the final sample consisted of 24 articles (Figure 1 ).

Two independent researchers (MSB and HEP) participated in all stages of this review to ensure its accuracy, including the search strategy, quality evaluation, extraction and analysis of data. Disagreements were resolved by discussion and consensus with two other reviewers (GCV and SSM).

\section{ANALYSIS AND PROCESSING OF DATA}

Two reviewers read and reviewed the articles independently for the systematic data extraction and recording. To this end, they used an instrument developed by the JBI, called Qualitative Data Extraction Instrument ${ }^{(21)}$. It includes the following information: title, authors, year of publication, journal, methodology, method, data analysis employed, configuration, geographical and cultural context, participants, interventions, main results and conclusions of authors and reviewers. After extracting this information, a level of credibility for each discovery was established, and the results were synthesized by representing the grouping of data from primary studies.

As established by the $\mathrm{JBI}^{(21)}$, in the grouping process, the findings were aggregated into subtopics by descriptive and conceptual similarity, and then grouped into broader and more comprehensive themes. In looking for similarities and differences between the perspectives of the different social actors who experienced the phenomenon under investigation, subtopics and themes were integrated, instead of compared. The following meta-theme was identified: "A pendular perspective: different views on family presence during cardiopulmonary resuscitation and invasive procedures" (Chart 1). For greater precision to the data grouping process, divergences were discussed by the group until reaching consensus. 


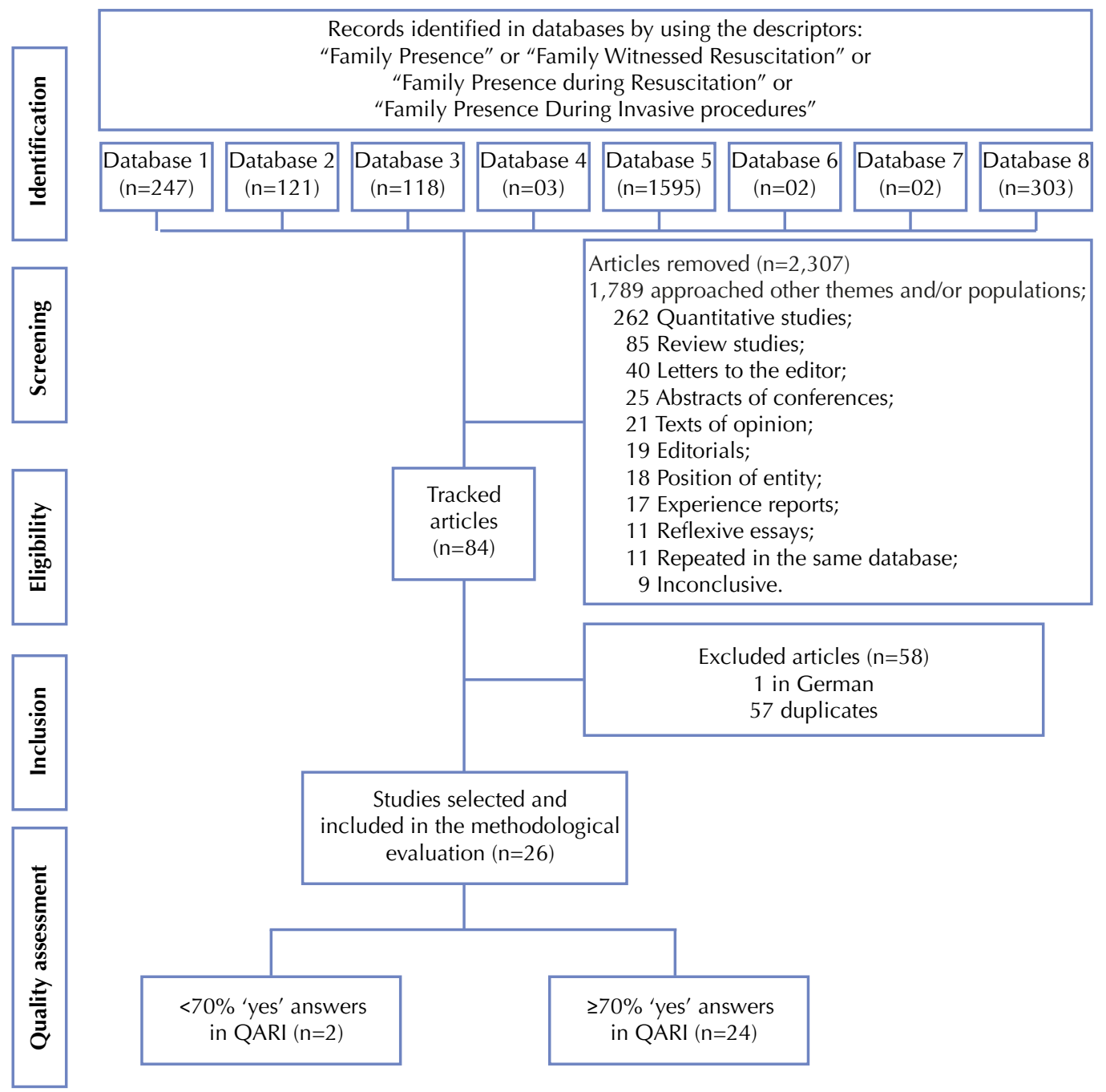

Legend: Base 1: Web of Science; Base 2: CINAHL; Base 3: LILACS; Base 4: PsycInfo; Base 5: MEDLINE; Base 6: Embase; Base 07: VHL; Base 8: Scopus. Figure 1 - Flowchart of identification, selection and inclusion of meta-synthesis studies. 


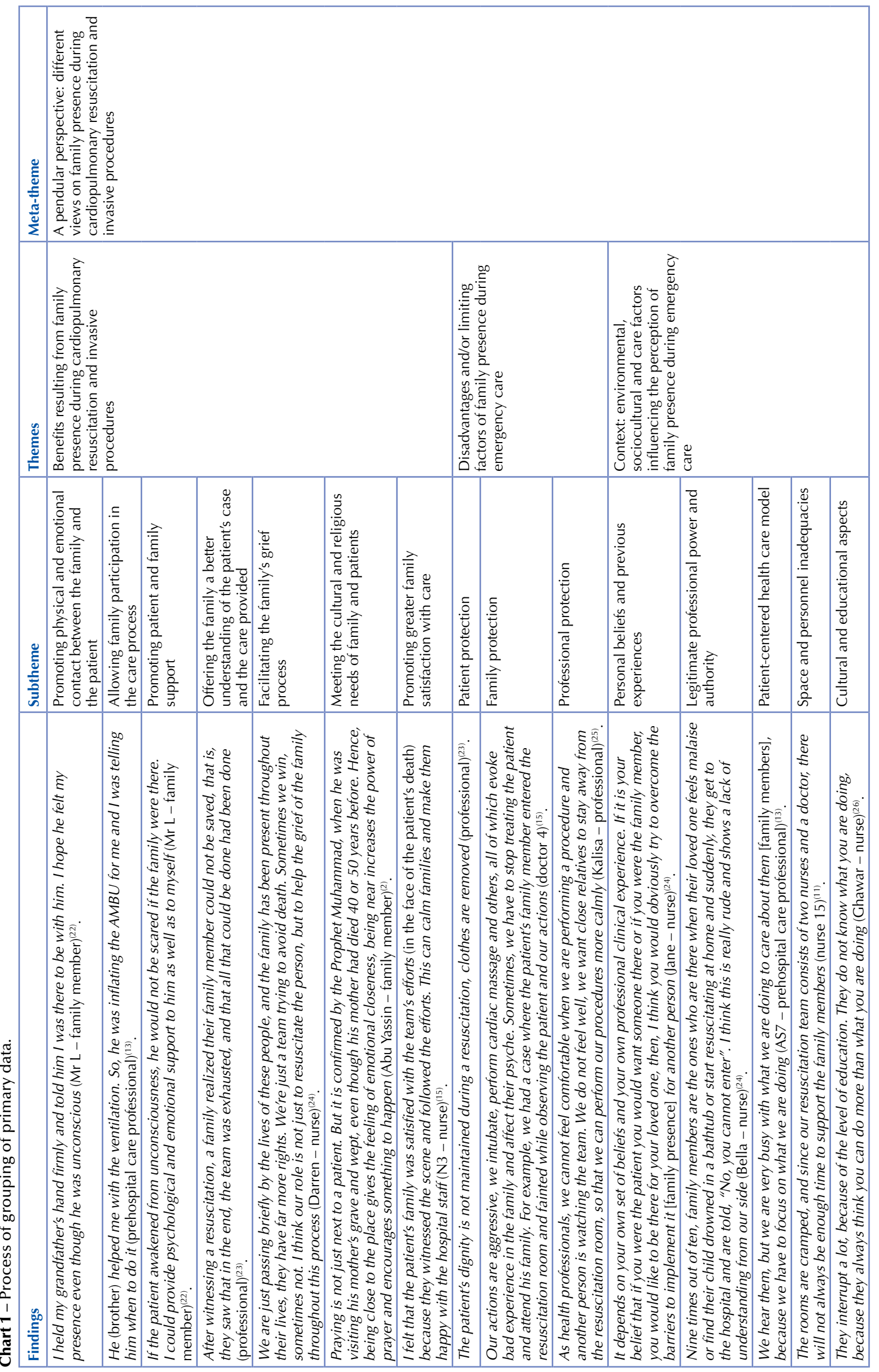




\section{RESULTS}

In this review, 24 articles showing the perception of family members and/or patients and/or health professionals about family presence during cardiopulmonary resuscitation and invasive procedures were included. Studies were conducted in several countries in the five continents. Participants included 83 patients, 128 family members, 1,192 health professionals and three chaplains (Chart 2).

Chart 2 - Summary of the characteristics of studies included in the meta-synthesis according to authors, year of publication, country, participants, context, type of study, method of analysis and percentage of positive responses in QARI.

\begin{tabular}{|c|c|c|c|c|c|c|}
\hline Author (year) & Country & Participants & Context & Type of study & Method of analysis & QARI (\%) \\
\hline Hung, et al. $(2010)^{(22)}$ & Hong Kong & 18 family members & Emergency department & Interpretative & Phenomenology & 90 \\
\hline Koberich, et al. $(2010)^{(11)}$ & Germany & 166 nurses & Intensive Care Units & Descriptive & Thematic analysis & 80 \\
\hline Wacht, et al. $(2010)^{(10)}$ & Israel & $\begin{array}{l}10 \text { professionals } \\
\text { (nurses and doctors) }\end{array}$ & Emergency department & Descriptive & Thematic analysis & 80 \\
\hline Davidson, et al. $(2011)^{(9)}$ & United States & $\begin{array}{l}12 \text { professionals } \\
\text { (nurses and doctors) }\end{array}$ & Emergency department & Interpretative & Grounded theory & 90 \\
\hline James, et al. $(2011)^{(27)}$ & $\begin{array}{l}\text { United } \\
\text { Kingdom }\end{array}$ & $\begin{array}{l}4 \text { nurses and } 3 \\
\text { chaplains }\end{array}$ & Emergency department & Descriptive & Content analysis & 80 \\
\hline Lowry, et al. $(2012)^{(12)}$ & United States & 14 nurses & Emergency department & Descriptive & $\begin{array}{c}\text { Conceptual content } \\
\text { analysis }\end{array}$ & 90 \\
\hline Dall'Orso, et al. $(2012)^{(5)}$ & Chile & $\begin{array}{l}33 \text { nurses and } 30 \\
\text { family members }\end{array}$ & $\begin{array}{l}\text { Mobile emergency } \\
\text { service }\end{array}$ & $\begin{array}{l}\text { Retrospective } \\
\text { exploratory }\end{array}$ & Thematic analysis & 80 \\
\hline Bashayreh, et al. $(2013)^{(28)}$ & Jordan & $\begin{array}{l}31 \text { professionals } \\
\text { (nurses, doctors, } \\
\text { anesthetists, } \\
\text { physiotherapists) }\end{array}$ & Intensive Care Units & Descriptive & Thematic analysis & 80 \\
\hline Leske, et al. $(2013)^{(6)}$ & United States & 28 family members & Emergency department & Descriptive & Content analysis & 100 \\
\hline Walker, et al. (2014) & $\begin{array}{l}\text { United } \\
\text { Kingdom }\end{array}$ & $\begin{array}{l}8 \text { prehospital } \\
\text { professionals and } 12 \\
\text { hospital nurses }\end{array}$ & $\begin{array}{l}\text { Prehospital and } \\
\text { hospital emergency } \\
\text { care settings }\end{array}$ & Interpretative & $\begin{array}{l}\text { Hermeneutic } \\
\text { phenomenology }\end{array}$ & 90 \\
\hline Monks, et al. $(2014)^{(14)}$ & $\begin{array}{l}\text { United } \\
\text { Kingdom }\end{array}$ & 6 nurses & Intensive Care Unit & Interpretative & Phenomenology & 90 \\
\hline Chapman, et al. $(2014)^{(23)}$ & Australia & $\begin{array}{l}77 \text { nurses and } 25 \\
\text { doctors }\end{array}$ & Emergency department & Descriptive & Content analysis & 90 \\
\hline Masa'Deh, et al. (2014) ${ }^{(2)}$ & Jordan & 7 family members & Emergency department & Descriptive & Thematic analysis & 80 \\
\hline Havugitanga, et al. $(2014)^{(25)}$ & Rwanda & $\begin{array}{l}6 \text { nurses and } 3 \\
\text { doctors }\end{array}$ & $\begin{array}{c}\text { Emergency Department } \\
\text { and Intensive Care } \\
\text { Unit }\end{array}$ & Descriptive & Content analysis & 90 \\
\hline Bashayreh, et al. $(2015)^{(26)}$ & Jordan & $\begin{array}{c}19 \text { nurses, } 7 \\
\text { doctors and } 5 \\
\text { physiotherapists }\end{array}$ & Intensive Care Unit & Exploratory & Thematic analysis & 90 \\
\hline Twibell, et al. $(2015)^{(7)}$ & United States & 48 patients & Emergency department & $\begin{array}{l}\text { Descriptive } \\
\text { exploratory }\end{array}$ & Thematic analysis & 90 \\
\hline Giles, et al. (2016) ${ }^{(24)}$ & Australia & $\begin{array}{c}18 \text { professionals, } 6 \\
\text { family members and } \\
1 \text { patient }\end{array}$ & Emergency department & Interpretative & Grounded theory & 90 \\
\hline Stefano, et al. $(2016)^{(4)}$ & France & 30 family members & $\begin{array}{l}\text { Mobile emergency } \\
\text { service }\end{array}$ & Interpretative & Grounded theory & 90 \\
\hline Soares, et al. $(2016)^{(8)}$ & Brazil & 29 patients & Emergency department & Descriptive & $\begin{array}{l}\text { Thematic content } \\
\text { analysis }\end{array}$ & 80 \\
\hline Youngson, et al. $(2017)^{(29)}$ & Australia & $\begin{array}{c}12 \text { professionals, } 9 \\
\text { family members and } \\
5 \text { patients }\end{array}$ & Emergency department & Descriptive & Thematic analysis & 80 \\
\hline Hassankhani, et a.I (2017) ${ }^{(15)}$ & Iran & $\begin{array}{l}12 \text { nurses and } 9 \\
\text { doctors }\end{array}$ & Emergency department & Interpretative & $\begin{array}{l}\text { Hermeneutic } \\
\text { phenomenology }\end{array}$ & 90 \\
\hline Porter, et al. $(2017)^{(30)}$ & Australia & $\begin{array}{c}17 \text { professionals } \\
\text { (doctors and nurses) }\end{array}$ & Emergency department & Case study & Thematic analysis & 90 \\
\hline San-Danskosky, et al. (2017) & $\begin{array}{l}\text { Finland and } \\
\text { Poland }\end{array}$ & $\begin{array}{l}168 \text { doctors and } \\
\text { nurses }\end{array}$ & $\begin{array}{c}\text { Emergency Department } \\
\text { and Intensive Care } \\
\text { Unit }\end{array}$ & Descriptive & $\begin{array}{l}\text { Inductive thematic } \\
\text { analysis }\end{array}$ & 90 \\
\hline Twibell, et al. $(2017)^{(32)}$ & United States & $\begin{array}{l}325 \text { nurses and } 193 \\
\text { doctors }\end{array}$ & Emergency department & $\begin{array}{l}\text { Descriptive } \\
\text { exploratory }\end{array}$ & Thematic analysis & 90 \\
\hline
\end{tabular}


A PENDULAR PERSPECTIVE: DIFFERENT VIEWS ON FAMILY PRESENCE DURING CARDIOPULMONARY RESUSCITATION AND INVASIVE PROCEDURES

In this study, the synthesis theme of "family presence" during cardiopulmonary resuscitation and invasive procedures was represented by a pendulum that oscillates between the extremities. Such a movement is influenced by the 'context', that is, the perception that 'benefits' or 'disadvantages and/or limitations' vary according to environmental, cultural and care conditions (Figure 2).

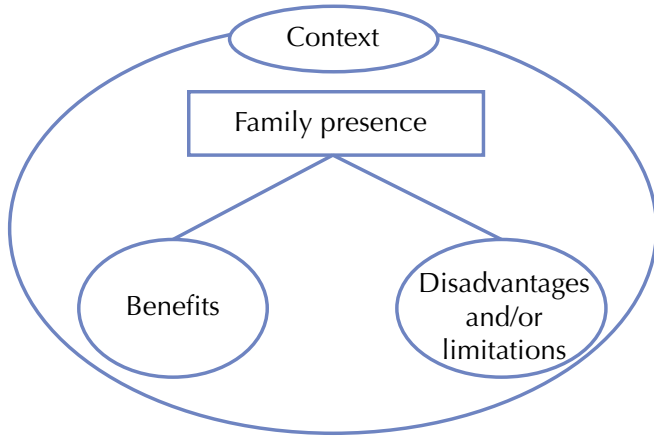

Figure 2 - List of themes identified in the review study.

\section{BENEFITS RESULTING FROM FAMILY PRESENCE DURING CARDIOPULMONARY RESUSCITATION AND INVASIVE PROCEDURES}

This theme involves the perceptions of benefits of family presence during cardiopulmonary resuscitation and invasive procedures. According to the studies analyzed, the benefits are: promoting physical and emotional contact between the family and the patient; allowing family participation in the care process; promoting patient and family support; offering the family a better understanding of the patient's case and the care provided; facilitating the family's grief process; meeting the cultural and religious needs of the family and the patient; and promoting greater family satisfaction.

\section{Promoting Physical and emotional contact BETWEEN THE FAMILY AND THE PATIENT}

For health professionals and family members, one of the benefits of family presence during cardiopulmonary resuscitation and invasive procedures is the possibility of promoting physical and emotional contact between the family member and the patient, which brings greater comfort for both ${ }^{(5,14,27-28)}$.

\section{AlLOWING FAMILY PARTICIPATION IN THE CARE PROCESS}

Some family members demonstrate they would like to feel involved in the care delivery process. They understand that offering information about the patient's initial clinical picture and underlying diseases to health professionals is a form of participation ${ }^{(4,22)}$. Professionals, in turn, point out that on several occasions, family members function as team members and "key informants"(13), and are necessary to "give useful information" ${ }^{(4)}$.
Professionals also perceive family members as potential helpers to perform less complex tasks ${ }^{(13,15)}$. Specifically in the case of prehospital care, they are useful to indicate where the patient is, the best place to perform care, and even assist in cardiac massage ${ }^{(4)}$. Professionals report that family presence can exercise a 'decision-making power' in the team and even set the time to end the resuscitation maneuvers ${ }^{(11-12,23)}$.

\section{PROMOTING PATIENT AND FAMILY SUPPORT}

Family members, health professionals and patients perceive family presence as an important strategy to offer support to patients and families. Family members ${ }^{(4,22)}$ and patients ${ }^{(7-8)}$ agree that if the family is present, they can support their loved ones by offering security, comfort and calm, thereby reducing fear, anguish and anxiety. Health professionals emphasize that by "putting themselves in the other's shoes" (14), they understand that the family can improve care at the end of life by ensuring the that patient is not alone at the moment of death ${ }^{(12,24)}$. This triggers care with greater dignity ${ }^{(23)}$, humanization ${ }^{(9)}$ and promotes "a calm atmosphere in the emergency room" ${ }^{(13)}$.

\section{OfFering tHe faMILY A BetTER UNDERSTANDING OF THE PATIENT'S CASE AND THE CARE PROVIDED}

Patients, family members and health professionals perceive that family presence allows a quicker access to information about the patients' clinical condition and their evolution $^{(2,5,7-8,22-23,29)}$.

In this direction, given the lack of information about the patient or when the communication process between professional and family is scarce, family members are more interested in accompanying emergency care and using alternative strategies to understand the situation ${ }^{(2,5,22,29-30)}$. For example, they observe verbal and non-verbal communication between health professionals more attentively, as well as the functioning of machines and devices connected to the patient ${ }^{(2,5)}$ or try to see inside the emergency room through the door gaps ${ }^{(5)}$. However, they often do not question professionals directly, as they perceive a withdrawn behavior is what it takes to enter and remain in this environment during assistance ${ }^{(22)}$.

Practitioners believe that family presence provides a better understanding of patient care and that "everything possible was done"(9,12,15,23-25). This allows the family to better understand the severity of the clinical picture ${ }^{(13)}$ and the case evolution $^{(12)}$. As a result, there is better acceptance of the final resuscitation outcome ${ }^{(15)}$, and less potential conflicts between family members and the health care staff ${ }^{(25)}$.

Finally, family presence allows patients and families to clearly understand the different roles played by relatives and health professionals in the face of emergency care for patients. Professionals are seen as necessary to 'fix' the patients, that is, their function is focused on treating traumatic, pathological and/or psychological disorders that led to the search for care ${ }^{(6)}$. Family members perform functions of protection, comfort and support, and offer information for professionals, patients and other relatives ${ }^{(6,8,29)}$. Therefore, in fact, family members do not appear concerned with checking the team's performance ${ }^{(22)}$. 


\section{FACILITATING THE FAMILY'S GRIEF PROCESS}

Professionals, family members and patients perceive family presence as a facilitator in the posterior grief process $^{(5-7)}$. The reason is that grief already begins as the care evolves and the expected results are not achieved ${ }^{(9,13)}$. Then, the family member can say goodbye to the loved one, confront internal and family conflicts, and reach the closure of the situation $^{(23-25)}$.

\section{Meeting the Cultural and Religious needs OF the FAMILY AND THE PATIENT}

Patients and family perceive the family presence during a moment of crisis as inherent in human nature ${ }^{(2)}$ and as children's obligation ${ }^{(22)}$. When respected these aspects, the family can maintain their customs in spite of being in an alien environment to their lives ${ }^{(8)}$. Moreover, family presence promotes the practice of religious customs and the exercise of faith through prayer, which calms patients and family members ${ }^{(2,7)}$.

\section{Promoting greater family satisfaction With CARE}

Finally, health professionals and family members perceive that family presence during resuscitation and invasive procedures promotes greater satisfaction with patient care. Families feel safer given the high number of people serving the patient, and the professionalism, cohesion and quick intervention of the team ${ }^{(5-6)}$. Thus, families have fewer complaints ${ }^{(26)}$, are grateful for receiving clear, sufficient and timely information ${ }^{(4,6)}$, for witnessing the service ${ }^{(4,6,15,24)}$ and perceiving that their unconscious family member did not suffer with the invasive procedures ${ }^{(4)}$.

The opposite is also true. Family members excluded from the emergency care of their loved one were dissatisfied with the lack of information and support ${ }^{(2,24)}$, and the fact that they could not say goodbye ${ }^{(8)}$. In addition, they were suspicious about care because of the understanding that "the family is excluded given the need to hide something"(2), and their distance from the sick relative causes intense suffering characterized by emotional instability, crying, anxiety and worries ${ }^{(29)}$.

\section{DiSADVANTAGES AND LIMITING FACTORS OF FAMILY PRESENCE DURING CARDIOPULMONARY RESUSCITATION AND INVASIVE PROCEDURES}

In this theme, the results of the perception of disadvantages and/or limitations on family presence during cardiopulmonary resuscitation and invasive procedures, which are mostly based on the protectionism discourse were grouped. Thus, when patients, family members and professionals are contrary to family presence, they justify their point by the need to guarantee protection to those involved in the process of providing, receiving and following up care.

\section{Patient protection}

In the perception of patients (self-protection) ${ }^{(7)}$ and health professionals ${ }^{(23-26)}$, patient protection arises as a limitation to family presence. Patients have expressed their concern with the family seeing them naked ${ }^{(7)}$. Professionals' concern is related to the belief that family presence diminishes the patient's dignity ${ }^{(25)}$, and sometimes prevents the continuation of procedures because of inappropriate family behavior, such as "throwing oneself over the patient"(24-25).

\section{FAMILY PROTECTION}

The discourse of family protection was recurrent among patients ${ }^{(7)}$, health professionals ${ }^{(9-10,12-15,24,26)}$ and family members (self-protection) ${ }^{(4)}$. For professionals, families should be prevented from watching the scenes produced during the service, which are characterized as "uncomfortable"(12), "strong"(14), "disturbing"(9), "traumatizing"(15), "shocking"(13), "horrible" (11) and "unbearable"(26). This momentarily prevents families from coping adequately with the situation ${ }^{(24)}$ which may cause fainting ${ }^{(11,15,26)}$, emesis ${ }^{(11)}$, hysterical behavior ${ }^{(11)}$, and even posterior psychological damage ${ }^{(15,25,32)}$.

To a lesser extent, some family members agree that care includes traumatic procedures ${ }^{(3-4)}$ hence, it is "aggressive" (3) and "shocking"(4). These same family members realize that some people are better prepared to cope with emotional stress, while others are not, and so they may feel nervous. Consequently, family members fear that the patient also suffers with stress and/or physiological changes by accompanying the suffering of their family ${ }^{(3-4)}$.

\section{Professional Protection}

Finally, most studies have reports from patients, family members and, mainly, health professionals, who are contrary to family presence as a way of protecting professionals. Patients believe that emotional responses from their family members can distract professionals and disrupt the provision of care $^{(7)}$. Indirectly, this can also be understood as patient protection. The relatives emphasized "they did not want to disturb" ${ }^{(5)}$ or "be in the middle of professionals' way" ${ }^{(24)}$. They understand that their presence may cause "inconvenience" to the team ${ }^{(22)}$. It is evident that patients and family members sometimes are contrary to family presence in order to meet the health professionals needs.

Professionals are emphatic in identifying that family presence: a) distracts the team, since the attention must be in multiple foci ${ }^{(5,13,31)}$; b) causes discomfort ${ }^{(23-25)}$ and stress in professionals ${ }^{(5,9-10,13,15,28)}$, because they do not wish to be observed and evaluated ${ }^{(5,9,14,24)}$; $)$ increases the workload, since resuscitation maneuvers are maintained for a longer time than as stated in protocols ${ }^{(23,25-26)}$; and d) inhibits team communication during the service ${ }^{(26)}$. Professionals want to protect themselves from the behavior of family members during care ${ }^{(23,32)}$. Above all, they report fear of being assaulted by the family when they do not understand the evolution of the case and do not accept death ${ }^{(11,15,22)}$.

According to the professionals, these aspects directly interfere in the team performance and provision of care to patients ${ }^{(25)}$. Family presence also makes it difficult to perform technical procedures, since it affects professionals' confidence and ability ${ }^{(9,14-15)}$ and triggers fear of making mistakes under 
the supervision of the family ${ }^{(26)}$, and these factors make their work harder to perform ${ }^{(10)}$. Therefore, family exclusion is often justified by the need to protect professionals from secondary and unnecessary stress that may influence their skills and abilities, especially with less experienced professionals ${ }^{(13-14)}$.

Professionals justify the exclusion of families for their self-protection against possible lawsuits. As they believe most families are unprepared to understand care, it may lead to misinterpretations about clinical decisions taken and procedures performed. Such interpretations can make family members feel that the health team is responsible for the bad results, thereby driving them to litigation against professionals and institutions ${ }^{(10,12-14,26)}$.

\section{CONTEXT: ENVIRONMENTAL, SOCIOCULTURAL AND CARE FACTORS INFLUENCING THE PERCEPTION OF FAMILY PRESENCE DURING RESUSCITATION AND INVASIVE PROCEDURES}

The divergence between the perceptions of professionals, family members and patients about family presence during cardiopulmonary resuscitation and invasive procedures, and the lack of consensus on the subject, are related to several contextual factors, such as: a) personal beliefs and previous experiences; b) legitimized professional power and authority; c) patient-centered health care model; d) inadequate space and personnel; e) cultural and educational aspects.

\section{Personal beliefs AND PReVIOUS eXPeriences}

Personal beliefs and previous experiences seem to interfere directly with the perception of family presence during care. Family members, patients and professionals have divergent beliefs about who is entitled to decide about family presence. For example, family members ${ }^{(22,24)}$ claim this right based on the property of the patient, while professionals believe they own the space and the act of care ${ }^{(24)}$. However, even among professionals, speeches are contradictory, because some understand this is a family right ${ }^{(23)}$, whereas others see it as a right of the team ${ }^{(26,28)}$. A third group identifies it as a right of the team, but as a family member, they believe it is their right to be present in the event if a family member needs service ${ }^{(10)}$. This demonstrates the presence of personal versus professional conflicts ${ }^{(11)}$.

Professionals who value the family and believe it is their right to be with the loved one during resuscitation and invasive procedures, are more likely to implement this practice $^{(23,26)}$. Previous positive experiences with family presence motivate the practice implementation by professionals, while negative experiences prevent/inhibit them from inviting other families ${ }^{(23)}$. Previous experiences with family presence have also been important for family members. Those who feel capable by having witnessed other emergency care situations for loved ones, wish to be present again, even in the face of negative outcomes such as death ${ }^{(2,4)}$.

\section{LEGITIMATE PROFESSIONAL POWER AND AUTHORITY}

Health professionals identify the emergency care environment as "untouchable"(24), and that even in prehospital care, they should be careful with possible occupational exposure $^{(13)}$. Therefore, people who assist the patient have authority and even a certain legitimized power to keep families excluded from this space ${ }^{(24)}$, even with the lack of institutional policies that prohibit family presence ${ }^{(26)}$. Some justify this exclusion with a patronizing and protective discourse that "they know what is best for patients and their families"(24). At the same time, they identify the family's compliance with their rules as subservience and professional dominance ${ }^{(13)}$. Faced with this scenario, family members themselves recognize a preconceived notion that families are not given the opportunity to accompany their loved one during care ${ }^{(22)}$, even if service is provided in their own home or public space ${ }^{(5)}$. They accept the professionals' decision with resignation ${ }^{(24)}$.

\section{Patient-Centered health CARE MODEL}

Health professionals identify the patient-centered health care model as a condition for family exclusion ${ }^{(13)}$. Assistance must also be based on scientific principles of rationality and not on emotionality ${ }^{(9)}$, because, as a rule, professionals need to be focused on patients with clinical worsening in an attempt to save their life ${ }^{(29)}$. As they believe it is impossible to offer support to families and interact with them, they indicate that family members should not be present during assistance ${ }^{(29)}$.

\section{SPACE AND PERSONNEL INADEQUACIES}

Health professionals identify that health services are unprepared for the reception and embracement of families who wish to accompany their loved ones during emergency care. They mention the limited number of employees ${ }^{(9-10)}$ and reduced physical space ${ }^{(9,11,23-24,27)}$. In addition, they state that family presence creates agglomerations ${ }^{(9)}$ by making the space insufficient for the adequate performance of their functions ${ }^{(23-24)}$, and invades patients' privacy ${ }^{(9)}$. Patients themselves express concerns about the small physical space for reception of the family ${ }^{(7)}$.

\section{Cultural and educational aspects}

Some health professionals, family members and patients point the direct influence of cultural and educational aspects on the effectiveness of family presence during emergency care $^{(2,8,26)}$. A study in Jordan found that family's lack of understanding prevents them from participating, and this is directly related to the lack of basic education of family members ${ }^{(26)}$.

In diverse cultures, different degrees of desire and effectiveness of family presence are identified. Among patients in South America ${ }^{(8)}$, there are fewer objections to family presence compared with North America ${ }^{(7)}$. Family members from the Middle East ${ }^{(2)}$ seek to exercise their faith more strongly during the presence, and seem to have a greater need to be with their loved one than those in Asia ${ }^{(22)}$. Health professionals from developing countries, such as Rwanda, in Africa ${ }^{(25)}$, perceive more risks and barriers compared to professionals from developed countries such as Australia ${ }^{(23)}$, United Kingdom $^{(14)}$ and United States ${ }^{(12)}$. 


\section{DISCUSSION}

This systematic review demonstrated an increasing interest in disseminating studies involving family presence during cardiopulmonary resuscitation and invasive procedures. This became clear because only one systematic review with a meta-synthesis on the same theme was identified in a 24-year period (1985 to 2009), in which 25 qualitative studies were analyzed ${ }^{(20)}$, whereas the present review addressed findings from 24 studies in an 8-year period (2010 to 2017).

The interest in this subject involves researchers from countries in the five continents of the world, which allows to produce different views on the same phenomenon, considering the cultural, economic and social nuances interfering in its existence, manifestation and understanding. This, in turn, can support the development of international guidelines that direct the formation of permissive institutional policies with family presence and consider local specificities ${ }^{(33)}$.

According to the evidence found, the perception of family presence during cardiopulmonary resuscitation and invasive procedures is a pendulum oscillating between 'benefits' and 'disadvantages and/or limitations'. The benefit is that family presence establishes an environment of physical and emotional support for patients and their families by reducing fear and insecurity in face of the situation ${ }^{(4,23)}$. It also promotes family participation, provides a better understanding of the care and even a better acceptance of grief, which ultimately triggers greater comfort between family and patients ${ }^{(9,23)}$. However, sometimes, there is little support for families during emergency care ${ }^{(23)}$. In this sense, family members reveal that when a loved one is in a critical state of health, they seek other sources of social, psychological and financial support, such as extended family, friends and religious practice ${ }^{(2)}$.

Negative aspects on family presence were also identified in the studies. The negative perception seems to be camouflaged in speeches that give the first impression that participants, particularly professionals, want to protect families and patients. There is concern that families may feel uncomfortable and traumatized by witnessing the care procedures ${ }^{(5,13,25)}$, which could have direct repercussions on team interventions and make their performance, which is exclusively focused on patients, more difficult ${ }^{(7,25)}$.

In fact, some family members feel dissatisfied when witnessing the emergency care of their loved one. In general, this dissatisfaction is more directly related to the lack of interaction with the health team ${ }^{(4,29)}$ than with scenes produced during the service. The lack of interaction between the family and health professionals triggers psychological overload and confusion in the family ${ }^{(29)}$, because they do not understand the scene and perceive the service as disorganized ${ }^{(4)}$.

A more in-depth analysis shows that professionals are more incisively concerned with a possible evaluation of family members, that is, any mistake could put to the test their skill and technical capacity and lead to litigation ${ }^{(5,14)}$. On the other hand, in the literature there are no reports on legal proceedings filed by family members who had been present in this type of care. Perhaps this is because families, as a rule, are more interested in supporting their loved ones at a time of crisis than directly supervising the team's work ${ }^{(22)}$. The family recognizes that during emergency care, professionals and family members have different roles ${ }^{(6)}$.

Many studies present this dichotomy of understanding, especially when they investigate the perception of different actors, such as professionals versus family versus patients ${ }^{(24)}$, or even from different professional categories, such as nurses versus doctors ${ }^{(25,32)}$. An integrative review study with 14 studies showed that nurses were more likely to accept family presence than doctors, and that care nurses were less supportive of the practice than those in managerial and research positions ${ }^{(34)}$. This difference is certainly a reflection of the greater or lesser awareness about PFCC and the importance given to the patient's family, including during cardiopulmonary resuscitation and invasive procedures.

The oscillation in the perception of benefits and disadvantages is influenced by the context of the actors involved, and varies according to environmental, cultural and care conditions. The most strongly identified environmental conditions were the absence of physical space (9,11,23-24) $^{2}$ and insufficient number of professionals to serve patients and their families ${ }^{(27-28)}$. Thus, before accepting family presence in emergency units, urgent adaptations must be made in the physical space, in addition to offering more human resources, especially a specific professional for preparation, user embracement, support and company to the family through emotional support and provision of information on the patient's health status ${ }^{(23,27)}$.

The presence of a facilitator is essential to enable the family to be with their loved one during resuscitation and invasive procedures ${ }^{(9,11-12,23-25,27-28,30)}$. The role of this professional is to prepare the family to live the experience, decode the scenes, meet their physical and emotional needs, accompany, support and advocate for the family's interests. After finishing the service, they must also be available to clarify any doubts of the family, and support them in the initial grief process $^{(9,11-13,24,27)}$. In order that facilitators can perform their functions, some attributes are crucial, namely: use of clear and accessible language for the family's understanding ${ }^{(27)}$, being an experienced person ${ }^{(24)}$, of the same culture of the family and patient ${ }^{(28)}$, honest with the family, demonstration of interest in the family's suffering ${ }^{(28)}$ and able to form a bond with the family member ${ }^{(14)}$.

The findings of this review reinforce, update and broaden the existing understanding about family presence during cardiopulmonary resuscitation and invasive procedures, especially when compared with another meta-synthesis on the subject ${ }^{(20)}$. In such a study, a tension between family members (because of the belief in their right to be present) and professionals (because of the belief in their control over the practice) was observed ${ }^{(20)}$. On the other hand, the present review has expanded the understanding on this tension, which still remains and is not crystallized, oscillating between the perception of 'benefits' and 'disadvantages and/ or limitations'. It varies not only according to the subject that perceives it, but also depends on environmental, cultural and assistance factors which fom the subjects' context. 
The patients' perception - although they are concerned with the protection of the family, professionals and their self-protection - is similar to that of the family member, i.e., they want the performance of the service. This aspect presents a new perspective in this complex process (family insertion in the emergency context) that must be considered by professionals during resuscitation and invasive procedures. Thus, the inclusion of patients' perception is a strength of this review given the need to understand the family presence and deliberate about it in an extended way that considers the opinions and wishes of patients and their closest relatives, as well as the conditions surrounding the professional decision and the sociocultural context where care is provided ${ }^{(25,27-28)}$, which will enable a more qualified family presence.

Some limitations of the study are: 1) Possibility of loss of some relevant studies in different languages. A broad search protocol was adopted with the purpose of including gray literature databases, and the initial capture resulted in 2,391 texts. 2) The findings are not intended to generalization and should be interpreted and applied carefully in the light of the experiences of each care context. Although the meta-synthesis of several qualitative studies build an increasingly robust understanding that is more likely to be transferable, qualitative research provides theoretical and contextual insights into the experiences of a limited number of people in specific environments. 3) Possibility of polarization of results, since cardiopulmonary resuscitation and invasive procedures performed in prehospital and hospital settings have very different connotations, and only three studies in this review were conducted in prehospital care, which did not allow conclusions about discrepancies between family presence in the hospital and extra-hospital space. Nonetheless, the inclusion of these studies was useful to expand the understanding of the phenomenon under investigation, since the signs indicate that in this scenario, the family may gain in some cases another connotation: of professionals' assistant.

\section{CONCLUSION}

The analysis and synthesis of the results of the 24 articles with qualitative data identified the meta-theme: "A pendular perspective: different views on family presence during cardiopulmonary resuscitation and invasive procedures", which shows that the perception of health professionals, family members and patients varies between the identification of benefits and disadvantages and/or limitations. Such perception is influenced by each subject's context, and environmental, sociocultural and care factors modify this understanding.

The perception of family members, patients and health professionals about family presence during cardiopulmonary resuscitation and invasive procedures is still controversial. Health institutions and their professionals must begin to discuss the PFCC and consider the possibility of allowing family presence during emergency care. In order to do so, institutional policies must be developed by taking into consideration the specific characteristics of each service for the technical and legal support of professionals' decisions. Even if there are institutional policies, family presence should not be a rule to be followed in all situations. In fact, each unit should have a policy that encourages and supports its professionals, but the evaluation of the case and final decision should be left to the team, considering the opinions of family members and patients whenever possible.

Individualized assessment of each case should occur by considering the preferences of patients and their family members, the severity of the clinical condition, the complexity of invasive procedures, the emotional responsiveness of the family, the defense mechanisms of the family to experience this situation, the preparation and training of health teams, the structural conditions of the unit, among other factors. Moreover, this evaluation must occur continuously throughout the care process.

The performance of a family facilitator is recommended for the integral follow-up (before, during and after the experience) of the family member and for health professionals' preparation, both during academic training and continuing education. These recommendations may favor the creation of a 'culture of family presence', in which the perception of benefits and positive experiences overlap perceptions of disadvantages and/or limitations.

Given the results, there must be development of new research on: a) identifying the feasible, replicable and more satisfactory strategies in relation to family acceptance in these environments; and b) implementing interventions that allow family presence during emergency care in scenarios with different characteristics in order to evaluate the indication, adequacy and adaptability of this practice, as well as the impact on the team, patients and families.

\section{RESUMO}

Objetivo: Sintetizar as melhores evidências qualitativas atinentes à percepção de familiares, pacientes e profissionais de saúde sobre a presença da família durante a ressuscitação cardiopulmonar e procedimentos invasivos. Método: Revisão sistemática com metassíntese realizada nas bases: Web of Science, Scopus, CINAHL, PsycINFO, LILACS, MEDLINE, Embase e BVS, abordando artigos publicados entre 2010 e 2017, os quais foram avaliados com o uso do Qualitative Data Extraction Instrument. Resultados: Foram encontrados 2.391 artigos, selecionados 26 e analisados 24. Identificou-se o metatema: "uma perspectiva pendular: diferentes olhares sobre a presença da família durante a ressuscitação cardiopulmonar e procedimentos invasivos”, o qual é sustentado pelos temas: Benefícios decorrentes da presença familiar, Desvantagens e/ou limitadores da presença familiar e Contexto: condicionantes ambientais, socioculturais e assistenciais que influenciam a percepção da presença familiar. Conclusão: A percepção de familiares, pacientes e profissionais sobre a presença da família ainda é controversa. A sensibilização desses sujeitos pode potencializar a prática, tornando-a mais sistematizada e qualificada.

\section{DESCRITORES}

Reanimação Cardiopulmonar; Serviços Médicos de Emergência; Relações Familiares; Relações Profissional-Família; Enfermagem em Emergência; Revisão. 
RESUMEN

Objetivo: Sintetizar las mejores evidencias cualitativas concernientes a la percepción de familiares, pacientes y profesionales sanitarios acerca de la presencia de la familia durante la resucitación cardiopulmonar y procedimientos invasivos. Método: Revisión sistemática con metasíntesis llevada a cabo en las bases: Web of Science, Scopus, CINAHL, PsycINFO, LILACS, MEDLINE, Embase y BVS, abordando artículos publicados entre 2010 y 2017, los que fueron evaluados con el uso del Qualitative Data Extraction Instrument. Resultados: Fueron encontrados 2.391 artículos, seleccionados 26 y analizados 24 . Se identificó el metatema: "una perspectiva pendular: diferentes miradas hacia la presencia de la familia durante la resucitación cardiopulmonar y procedimientos invasivos", el que se sostiene por los temas: Beneficios consecuentes de la presencia familiar, Desventajas y/o limitadores de la presencia familiar y Contexto: condiciones del entorno, socioculturales y asistenciales que influencian la percepción de la presencia familiar. Conclusión: La percepción de familiares, pacientes y profesionales sanitarios acerca de la presencia de la familia es todavía controvertida. La sensibilización de esos sujetos puede potenciar la práctica, haciéndola más sistematizada y cualificada.

\section{DESCRIPTORES}

Reanimación Cardiopulmonar; Servicios Médicos de Urgencia; Relaciones Familiares; Relaciones Profesional-Familia; Enfermería de Urgencia; Revisión.

\section{REFERENCES}

1. Ganz FD, Yoffe F. Intensive care nurses' perspectives of family-centered care and their attitudes toward family presence during CPR. J Cardiovasc Nurs. 2012;27(3):220-7.

2. Masa'Deh R, Saifan A, Timmons S, Nairn S. Families' stressors and needs at time of cardio-pulmonary resuscitation: Jordanian perspective. Glob J Health Sci [Internet]. 2013 [cited 2017 Jan 25];6(2):72-85. Available from: https://www.ncbi.nlm.nih.gov/pmc/articles/PMC4825218/

3. Doyle CJ, Post H, Burney RE, Maino J, Keefe M, Rhee KJ. Family participation during resuscitation: An option. Ann Emerg Med. 1987;16(6):673-5. DOI: http://dx.doi.org/10.1016/S0196-0644(87)80069-0

4. Stefano C, Normand D, Jabre P, Azoulay E, Kentish-Barnes N, Lapostolle F, et al. Family presence during resuscitation: qualitative analysis from a national multicenter randomized clinical trial. PloS One [Internet]. 2016 [cited 2017 Feb 10];11(6):e0156100. Available from: https://www.ncbi.nlm.nih.gov/pmc/articles/PMC4890739/

5. Dall'Orso MS, Concha PJ. Presencia familiar durante la reanimación cardiopulmonar: la mirada de enfermeros y familiares. Cienc Enferm [Internet]. 2012 [citado 2017 jan. 03];18(3):83-99. Disponible en: http://www.scielo.cl/pdf/cienf/v18n3/art_09.pdf

6. Leske JS, McAndrew NS, Brasel KJ. Experiences of families when present during resuscitation in the Emergency Department after trauma. J Trauma Nurs. 2013;20(2):77-85. DOI: 10.1097/JTN.0b013e31829600a8

7. Twibell RS, Craig S, Siela D, Simmonds S, Thomas C. Being There: Inpatients' perceptions of family presence during resuscitation and invasive cardiac procedures. Am J Crit Care. 2015;24(6):108-16. DOI: 10.4037/ajcc2015470.

8. Soares JR, Martin AR, Rabelo JF, Barreto MS, Marcon SS. Presença da família durante o atendimento emergencial: percepção do paciente vítima de trauma. Aquichan [Internet]. 2016 [citado 2017 fev. 25];16(2):193-204. Disponível em: http://www.scielo.org.co/pdf/aqui/ v16n2/v16n2a07.pdf

9. Davidson JE, Buenavista R, Hobbs K, Kracht K. Identifying factors inhibiting or enhancing family presence during resuscitation in the Emergency Department. Adv Emerg Nurs J. 2011;33(4):336-43. DOI: 10.1097/TME.0b013e318234e6a0

10. Wacht O, Dopelt K, Snir Y, Davidovitch N. Attitudes of Emergency Department staff toward family presence during resuscitation. Isr Med Assoc J. 2010;12(6):366-70.

11. Koberich S, Kaltwasser A, Rothaug O, Albarran J. Family witnessed resuscitation - experience and attitudes of German intensive care nurses. Nurs Crit Care. 2010;15(5):241-50. DOI: 10.1111/j.1478-5153.2010.00405.x

12. Lowry E. "It's just what we do": a qualitative study of emergency nurses working with well-established family presence protocol. J Emerg Nurs. 2012;38(4):329-34. DOI: 10.1016/j.jen.2010.12.016.

13. Walker WM. Emergency care staff experiences of lay presence during adult cardiopulmonary resuscitation: a phenomenological study. Emerg Med J. 2014;31(6):453-8.DOI: 10.1136/emermed-2012-201984.

14. Monks J, Flynn M. Care, compassion and competence in critical care: A qualitative exploration of nurses' experience of family witnessed resuscitation. Intensive Crit Care Nurs. 2014;30(6):353-9. DOI: 10.1016/j.iccn.2014.04.006.

15. Hassankhani H, Zamanzadeh V, Rahmani A, Haririan H, Porter JE. Family presence during resuscitation: a double-edged sword. J Nurs Scholarsh. 2017;49(2):127-34. DOI: 10.1111/jnu.12273

16. Sak-Dankosky N, Andruszkiewicz P, Sherwood PR, Kvist T. Integrative review: nurses' and physicians' experiences and attitudes towards inpatient-witnessed resuscitation of an adult patient. J Adv Nurs. 2014;70(5):957-74. DOI: 10.1111/jan.12276

17. Porter J, Cooper SJ, Sellick K. Attitudes, implementation and practice of family presence during resuscitation (FPDR): a quantitative literature review. Int Emerg Nurs. 2013;21(1):26-34. DOI: https://doi.org/10.1016/j.ienj.2012.04.002

18. Flanders SA, Strasen JH. Review of evidence about family presence during resuscitation. Crit Care Nurs Clin North Am. 2014;26(4):53350. DOI: 10.1016/j.ccell.2014.08.010

19. Oczkowski SJW, Mazzetti I, Cupido C, Fox-Robichaud AE. The offering of family presence during resuscitation: a systematic review and meta-analysis. J Intensive Care. 2015;3:41. DOI: 10.1186/s40560-015-0107-2

20. Rittenmeyer L, Huffman D. How families and health care practitioners experience family presence during resuscitation and invasive procedures. JBI Libr Syst Rev. 2012;10(31):1785-882.

21. Joanna Briggs Institute. Reviewers' manual 2015 methodology for JBI scoping reviews. Adelaide, Australia: Royal Adelaide Hospital; 2015. 
22. Hung MSY, Pang SMC. Family presence preference when patients are receiving resuscitation in an accident and emergency department. J Adv Nurs. 2011;67(1):56-67. DOI: 10.1111/j.1365-2648.2010.05441.x

23. Chapman R, Bushby A, Watkins R, Combs S. Australian Emergency Department health professionals' reasons to invite or not invite family witnessed resuscitation: a qualitative perspective. Int Emerg Nurs. 2014;22(1):18-24. DOI: 10.1016/j.ienj.2013.03.008.

24. Giles T, Lacey S, Muir-Cochrane E. Factors influencing decision-making around family presence during resuscitation: a Grounded Theory study. J Adv Nurs. 2016;72(11):2706-17. DOI: 10.1111/jan.13046

25. Havugitanga P, Brysiewicz P. Exploring healthcare professionals' perceptions regarding family-witnessed resuscitation in a hospital in Kigali, Rwanda. South Afr J Crit Care. 2014;30(1):18-21. DOI: http://dx.doi.org/10.7196/sajcc.174

26. Bashayreh I, Saifan A, Batiha AM, Timmons S, Nairn S. Health professionals' perceptions regarding family witnessed resuscitation in adult critical care settings. J Clin Nurs. 2015;24(17-18):2611-9. DOI: 10.1111/jocn.12875

27. James J, Cottle E, Hodge RD. Registered nurse and health care Chaplains experiences of providing the family support person role during family witnessed resuscitation. Intensive Crit Care Nurs. 2011;27(1):19-26. DOI: 10.1016/j.iccn.2010.09.001

28. Bashayreh I, Saif A, Batiha AM, Ruz MEA. Family presence during CPR in Adult Critical Care Settings: Hearing the voice of Jordanian health professionals. Life Sci J. 2013;10(4):1738-48.

29. Youngson MJ, Currey J, Considine J. Current practices related to family presence during acute deterioration in adult emergency department patients. J Clin Nurs. 2017;26(21-22):3624-35. DOI: 10.1111/jocn.13733

30. Porter JE, Miller N, Giannis A, Coombs N. Family Presence During Resuscitation (FPDR): observational case studies of emergency personnel in Victoria, Australia. Int Emerg Nurs. 2017;33:37-42. DOI: http://dx.doi.org/10.1016/j.ienj.2016.12.002

31. Sak-Dankosky N, Andruszkiewicz P, Sherwood PR, Kvist T. Health care professionals' concerns regarding in-hospital family-witnessed cardiopulmonary resuscitation implementation into clinical practice. Nurs Crit Care. 2018;23(3):134-40.

32. Twibell R, Siela D, Riwitis C, Neal A, Waters N. A qualitative study of factors in nurses' and physicians' decision-making related to family presence during resuscitation. J Clin Nurs. 2018;27(1-2):e320-34.

33. Polit DF, Beck CT. Essentials of nursing research, methods, appraisal, and utilization. Philadelphia: Lippincott Williams and Wilkins; 2014.

34. Fernandes AP, Carneiro CS, Geocze L, Santos VB, Guizilini S, Moreira RSL. Experiences and opinions of health professionals in relation to the presence of the family during in-hospital cardiopulmonary resuscitation: an integrative review. J Nurs Educ Pract. 2014; 4(5):85-94. DOI: https://doi.org/10.5430/jnep.v4n5p85 